\title{
ADOPSI PETANI TERHADAP INOVASI TANAMAN PADI SAWAH ORGANIK DI DESA MOLOMPAR KECAMATAN TOMBATU TIMUR, KABUPATEN MINAHASA TENGGARA
}

\author{
Welson M. Wangke \\ Benu Olfie, L. Suzana
}

\begin{abstract}
The objective of this research is to know the Innovation Adoption of Organic rice farmers in Tombatu Village Molompar Eastern District o Southeast Minahasa Regency and determine factors underlying farmers to adopt organic farming systems, especially organic rice. The study lasted for 3 (three) months, starting from December 2015 to March 2016. The determination of the territories in which the sample is determined by using the model of purposive sampling. For the research sample was taken 10 percent of the population that is 41 organic paddy rice farmers in the Molompar Village. The results showed that the adoption rate of organic paddy rice high enough that most farmers have implemented or adopted the organic paddy rice; based on the speed of innovation adoption of organic rice paddy, earlyimplemented farmer groups was categorized as the most speed of innovation adoption of organic paddy rice; there is a relationship between the level of age, education, extensive land ownership and income. Younger age, higher education, ownership of land, and the high revenue level tend to be of higher organic rice paddy level of adoption.
\end{abstract}

Key words: Innovation Adoption of organic rice, Molompar Village, Southeast Minahasa

\begin{abstract}
ABSTRAK
Penelitian ini bertujuan untuk, mengetahui Adopsi Petani terhadap Inovasi Padi Sawah Organik di Desa Molompar Kecamatan Tombatu Timur Kabupaten Minahasa Tenggara dan mengetahui Faktor-faktor yang melatarbelakangi petani untuk mengadopsi sistem pertanian organik khususnya padi organik. Penelitian ini berlangsung selama 3 (tiga) bulan yaitu Awal Bulan Desember 2015 sampai Maret 2016. Penentuan wilayah yang menjadi sampel penelitian ditentukan dengan menggunakan model purposive sampling. Untuk sampel penelitian diambil 10 persen dari populasi yaitu 41 orang petani padi sawah organik yang ada di Desa Molompar. Hasil penelitian menunjukkan bahwa; Tingkat adopsi padi sawah organik cukup tinggi dimana sebagian besar petani telah menerapkan atau mengadopsi padi sawah organik; berdasarkan kecepatan adopsi inovasi padi sawah organik, golongan petani pengetrap dini dan pengetrap awal paling banyak kecepatan adopsi inovasi padi sawah organik; terdapat hubungan antara tingkat umur, pendidikan, luas pemilikan lahan dan pendapatan. Umur muda, pendidikan lebih tinggi, pemilikan lahan yang luas, dan pendapatan yang tinggi cenderung tingkat adopsi inovasi padi sawah organik lebih tinggi.
\end{abstract}

Kata kunci: Adopsi, inovasi, padi sawah organik. Desa Molompar, Kabupaten Minahasa Tenggara 


\section{PENDAHULUAN}

\section{Latar Belakang}

Pangan merupakan kebutuhan dasar manusia untuk melanjutkan kehidupan. Kebutuhan pangan manusia berasal dari tumbuh-tumbuhan (pertanian primer) serta ternak dan ikan (pertanian sekunder), pangan yang dibutuhkan harus sehat dalam arti memiliki nilai gizi yang optimal seperti: vitamin, mineral, karbohidrat, lemak dan lainnya.

Di Indonesia pertanian organik baru dikenal awal tahun 1990-an. Pertanian Organik merupakan kegiatan bercocok tanam yang akrab dengan lingkungan. Pertanian organik berusaha meminimalkan dampak negatif bagi alam sekitar. Ciri utama pertanian organik adalah penggunaan varietas lokal yang relatif masih alami, diikuti dengan penggunaan pupuk organik dan pestisida organik. Pertanian organik merupakan tuntutan zaman, bahkan sebagai pertanian masa depan. Akhir-akhir ini kesadaran manusia untuk menjaga kelestarian lingkungan makin meningkat (Andoko, 2002).

Munculnya teknologi sistem pertanian organik sebagai bagian dari sistem pertanian berkelanjutan yang merupakan salah satu jawaban atas terjadinya degradasi terhadap lingkungan pertanian, ketergantungan petani terhadap komponen revolusi hijau dan lunturnya kearifan-kearifan lokal pada diri petani adalah sangat penting untuk mendapatkan perhatian yang serius untuk mengatasi adanya permasalahan tersebut. Sistem pertanian organik di Indonesia masih merupakan gerakan yang sangat terbatas, yang belum mendapat dukungan sepenuhnya dari pihak pemerintah, peneliti maupun petani, sehingga diperlukan langkah-langkah strategis untuk mengkomunikasikan teknologi sistem pertanian organik kepada masyarakat petani. Oleh karena itu peranan metode pendekatan dalam menyampaikan suatu inovasi agar petani bersedia mengadopsi teknologi tersebut menjadi sangat penting untuk mensosialisasikan sistem pertanian organik, sehingga dalam konteks pemikiran inilah maka proses adopsi dan difusi teknologi, menjadi sangat penting untuk mendapatkan perhatian secara mendalam. Berdasarkan uraian diatas maka menarik untuk diteliti proses adopsi inovasi padi sawah organik ( Sumarto H, 2003).

Kabupaten Minahasa Tenggara merupakan salah satu kabupaten yang memiliki lahan pertanian yang luas di Provinsi Sulawesi Utara dengan sebagian besar penduduknya bermata pencaharian sebagai petani. Luas lahan dan produksi padi sawah di Kecamatan Tombatu Timur sebesar 1998 Ha lebih tinggi jika dibandingkan dengan 11 kecamatan lainnya di Minahasa Tenggara, olehnya lokasi ini (Desa Molompar) Kecamatan Tombatu Timur dipilih sebagai lokasi penelitian.

\section{Tanaman Padi}

Padi merupakan tanaman pangan berupa rumput berumpun. Tanaman pertanian kuno berasal dari dua benua yaitu Asia dan Afrika Barat tropis dan subtropis. Bukti sejarah memperlihatkan bahwa penanaman padi di Zhejiang (Cina) sudah dimulai pada 3.000 tahun SM. Fosil butir padi dan gabah ditemukan di Hastinapur Uttar Pradesh India sekitar 100-800 SM. Selain Cina dan India, beberapa wilayah asal padi adalah, Bangladesh Utara, Burma, Thailand, Laos, Vietnam.

Terdapat 25 spesies Oryza, yang dikenal adalah $O$. sativa dengan dua subspecies yaitu Indica (padi bulu) yang ditanam di Indonesia dan Sinica (padi cere). Padi dibedakan dalam dua tipe yaitu padi kering (gogo) yang ditanam di dataran tinggi dan padi sawah di dataran rendah yang memerlukan penggenangan.

Varitas unggul nasional berasal dari Bogor: Pelita I/1, Pelita I/2, Adil dan Makmur (dataran tinggi), Gemar, Gati, GH 19, GH 34 dan GH 120 (dataran rendah). Varitas unggul introduksi dari International Rice Research Institute (IRRI) Filipina adalah jenis IR atau PB yaitu IR 22, IR 14, IR 46 dan IR 54 (dataran rendah); PB32, PB 34, PB 36 dan PB 48 (dataran rendah), ( Suparyono, dkk, 1994).

\section{Adopsi}

Adopsi pada hakekatnya dapat diartikan sebagai proses penerimaan inovasi dan atau perubahan perilaku yang berupa : pengetahuan (cognitive), sikap (affective), maupun 
keterampilan (psychomotoric) pada diri seseorang setelah menerima "inovasi" yang disampaikan fasilitator oleh masyarakat penerimanya.

Proses adopsi inovasi juga dapat didekati dengan pemahaman bahwa proses adopsi inovasi itu sendiri merupakan proses yang diupayakan secara sadar demi tercapainya tujuan pembangunan. Sebagai suatu proses, pembangunan merupakan proses interaksi dari banyak pihak yang secara langsung maupun tak langsung terkait dengan upaya peningkatan pendapatan serta perbaikan mutu-hidup, melalui penerapan teknologi yang terpilih (Mardikanto, 1988).

Pada awalnya Rogers (1983) menerangkan bahwa dalam upaya perubahan seseorang untuk mengadopsi suatu perilaku yang baru, terjadi berbagai tahapan adopsi, yaitu:

1. Tahap Awareness (Kesadaran), yaitu tahap seseorang tahu dan sadar ada terdapat suatu inovasi sehingga muncul adanya suatu kesadaran terhadap hal tersebut.

2. Tahap Interest (Keinginan), yaitu tahap seseorang mempertimbangkan atau sedang membentuk sikap terhadap inovasi yang telah diketahuinya tersebut sehingga ia mulai tertarik pada hal tersebut.

3. Tahap Evaluation (Evaluasi), yaitu tahap seseorang membuat putusan apakah ia menolak atau menerima inovasi yang ditawarkan sehingga saat itu ia mulai mengevaluasi.

4. Tahap Trial (Mencoba), yaitu tahap seseorang melaksanakan keputusan yang telah dibuatnya sehingga ia mulai mencoba suatu perilaku yang baru.

5. Tahap Adoption (Adopsi), yaitu tahap seseorang memastikan atau mengkonfirmasikan putusan yang diambilnya sehingga ia mulai mengadopsi perilaku baru tersebut. Kecepatan adopsi dipengaruhi oleh faktor sebagai berikut:

a. Sifat-sifat atau karakteristik inovasi

b. Sifat-sifat atau karakteristik calon pengguna

c. Pengambilan keputusan adopsi

d. Saluran atau media yang digunakan

e. Kualifikasi fasilitator

\section{Inovasi}

Inovasi adalah suatu gagasan, praktek, atau benda yang dianggap/dirasa baru oleh individu atau kelompok masyarakat. Ungkapan dianggap/dirasa baru terhadap suatu ide, praktek atau benda oleh sebagian orang, belum tentu juga pada sebagian yang lain. Kesemuanya tergantung apa yang dirasakan oleh individu atau kelompok terhadap ide, praktek atau benda tersebut.

Penerimaan atau penolakan suatu inovasi adalah keputusan yang dibuat seseorang/individu dalam menerima suatu inovasi. Menurut Rogers (1983), proses pengambilan keputusan inovasi adalah proses mental dimana seseorang/individu berlalu dari pengetahuan pertama mengenai suatu inovasi dengan membentuk suatu sikap terhadap inovasi, sampai memutuskan untuk menolak atau menerima, melaksanakan ide-ide baru dan mengukuhkan terhadap keputusan inovasi.

Rogers (1983) merevisi kembali teorinya tentang keputusan inovasi yaitu: Knowledge (pengetahuan), Persuasion (persuasi), Decision (keputusan), Implementation (pelaksanaan), dan Confirmation (konfirmasi).

1. Tahap pengetahuan. Dalam tahap ini, seseorang belum memiliki informasi mengenai inovasi baru. Untuk itu informasi mengenai inovasi tersebut harus disampaikan melalui berbagai saluran komunikasi yang ada, bisa melalui media elektronik, media cetak, maupun komunikasi interpersonal di antara anggota masyarakat. Tahapan ini juga dipengaruhi oleh beberapa karakteristik dalam pengambilan keputusan, yaitu: (1) Karakteristik sosial-ekonomi, (2) Nilai-nilai pribadi dan (3) Pola komunikasi.

2. Tahap persuasi. Pada tahap ini individu tertarik pada inovasi dan aktif mencari informasi/detail mengenai inovasi. Tahap kedua ini terjadi lebih banyak dalam tingkat pemikiran calon pengguna. Inovasi yang dimaksud berkaitan dengan karakteristik inovasi itu sendiri, seperti: (1) kelebihan inovasi, (2) tingkat keserasian, (3) kompleksitas, (4) dapat dicoba dan (5) dapat dilihat.

3. Tahap pengambilan keputusan. Pada tahap ini individu mengambil konsep inovasi dan menimbang keuntungan/kerugian dari 
menggunakan inovasi dan memutuskan apakah akan mengadopsi atau menolak inovasi.

4. Tahap implementasi. Pada tahap ini mempekerjakan individu untuk inovasi yang berbeda-beda tergantung pada situasi. Selama tahap ini individu menentukan kegunaan dari inovasi dan dapat mencari informasi lebih lanjut tentang hal itu.

5. Tahap konfirmasi. Setelah sebuah keputusan dibuat, seseorang kemudian akan mencari pembenaran atas keputusan mereka. Tidak menutup kemungkinan seseorang kemudian mengubah keputusan yang tadinya menolak jadi menerima inovasi setelah melakukan evaluasi.

Sifat-sifat intrinsik inovasi mencakup:

a. Informasi ilmiah yang melekat/dilekatkan pada inovasi

b. Nilai-nilai atau keunggulan-keunggulan yang melekat pada inovasinya

c. Tingkat kerumitan inovasi

d. Mudah/tidaknya dikomunikasikan atau kekomunikatifan inovasi

e. Mudah/tidaknya inovasi tersebut dicobakan

f. Mudah/tidaknya inovasi tersebut diamati

Sifat-sifat ekstrinsik inovasi meliputi:

a. Kesesuaian (compatibility) inovasi dengan lingkungan setempat

b. Tingkat keunggulan relative dari inovasi yang ditawarkan, atau keunggulan lain yang dimiliki oleh inovasi dibanding dengan teknologi yang sudah ada yang akan diperbaharui/digantikannya; baik keunggulan teknis, keunggulan ekonomis, manfaat non ekonomi, maupun dampak social budaya dan politis yang ditimbulkannya.

Sehubungan dengan ragam golongan masyarakat ditinjau dari kecepatannta mengadopsi inovasi, Lionberger (1960) mengemukakan beberapa faktor yang mempengaruhi kecepatan seseorang untuk mengadopsi inovasi yang meliputi:

1. Luas skala-usaha, semakin luas biasanya semakin cepat mengadopsi, karena memiliki kemampuan ekonomi yang lebih baik.

2. Tingkat pendapatan, seperti halnya tingkat luas usahatani, petani dengan tingkat pendapatan semakin tinggi biasanya akan semakin cepat mengadopsi inovasi.

3. Keberanian mengambil resiko, sebab pada tahap awal biasanya tidak selalu berhasil seperti yang diharapkan. Karena itu, individu yang memiliki keberanian mengahadapi resiko biasanya lebih inovatif.

4. Umur, semakin tua (di atas 50 tahun), biasanya semakin lamban mengadopsi inovasi dan cenderung hanya melaksanakan kegiatan-kegiatan yang sudah biasa diterapkan oleh warga msyarakat setempat.

5. Tingkat partisipasinya dalam kelompok/organisasi diluar lingkungannya sendiri. Warga masyarakat yang suka bergabung dengan orang-orang di luar sistem sosialnya sendiri, umumnya lebih inovatif dibanding mereka yang hanya melakukan kontak pribadi dengan warga masyarakat setempat.

6. Aktivitas mencari informasi dan ide-ide baru. Golongan masyarakat yang aktif mencari informasi dan ide-ide baru, biasanya lebih inovatif dibanding orangorang yang pasif apalagi yang selalu skeptic (tidak percaya) terhadap sesuatu yang baru.

\section{Rumusan Masalah}

Permasalahan dalam penelitian ini yaitu

1. Bagaimana proses Adopsi Inovasi Padi Sawah Organik oleh Petani di Desa Molompar Kecamatan Tombatu Timur Kabupaten Minahasa Tenggara?

2. Faktor apa saja yang melatarbelakangi petani untuk mengadopsi sistem pertanian organik khususnya padi organik?

\section{Tujuan dan Manfaat Penelitian}

Tujuan dan Manfaat Penelitian ini yaitu:

1. Mengetahui Adopsi Inovasi Padi Sawah Organik oleh Petani di Desa Molompar Kecamatan Tombatu Timur Kabupaten Minahasa Tenggara

2. Mengetahui Faktor-faktor yang melatarbelakangi petani untuk mengadopsi sistem pertanian organik khususnya padi organik 


\section{METODE PENELITIAN}

\section{Lokasi dan Waktu Penelitian}

Penelitian ini dilakukan di Desa Molompar Kecamatan Tombatu Timur. Penelitian ini berlangsung selama 3 (tiga) bulan yaitu Awal Bulan Desember 2015 sampai Maret 2016.

\section{Metode Pengambilan Sampel}

Penentuan wilayah yang menjadi sampel penelitian ditentukan dengan menggunakan model purposive sampling. Untuk sampel penelitian diambil 10 persen dari populasi yaitu 41 orang petani padi sawah organik yang ada di Desa Molompar.

\section{Jenis Data dan Sumber Data}

Jenis Data yang digunakan dalam penelitian ini adalah data primer dan sekunder. Data primer yaitu data yang diperoleh dengan melakukan survei langsung melalui wawancara langsung kepada responden dalam hal ini petani sesuai dengan kebutuhan analisis terkait dengan objek penelitian. Data sekunder yaitu data yang bersumber atau diperoleh dari kantor-kantor atau instansi-instansi yang terkait atau berhubungan dengan judul penelitian.

\section{Konsep Pengukuran Variabel}

Variabel yang diukur dalam penelitian ini adalah:

1. Karakteristik dari petani:

a. Umur responden

b. Pekerjaan: Pekerjaan utama : petani

Pekerjaan tambahan: PNS, swasta, tukang dsb

c. Tingkat pendidikan adalah SD,SMP,SMA dan PT

2. Pendapatan Petani Padi Organik (Rp/panen)

3. Bahan-bahan yang digunakan dalam pegolahan padi sawah organik

4. Tahapan adopsi, yaitu:

a. Tahap Awareness (Kesadaran), yaitu tahap petani tahu dan sadar ada terdapat suatu inovasi sehingga muncul adanya suatu kesadaran terhadap hal tersebut. b. Tahap Interest (Keinginan), yaitu tahap petani mempertimbangkan atau sedang membentuk sikap terhadap inovasi yang telah diketahuinya tersebut sehingga ia mulai tertarik pada hal tersebut.

c. Tahap Evaluation (Evaluasi), yaitu tahap petani membuat putusan apakah ia menolak atau menerima inovasi yang ditawarkan sehingga saat itu ia mulai mengevaluasi.

d. Tahap Trial (Mencoba), yaitu tahap petani melaksanakan keputusan yang telah dibuatnya sehingga ia mulai mencoba suatu perilaku yang baru.

e. Tahap Adoption (Adopsi), yaitu tahap petani memastikan atau mengkonfirmasikan putusan yang diambilnya sehingga ia mulai mengadopsi perilaku baru tersebut.

\section{Metode Analisis Data}

Metode analisis yang digunakan dalam penelitian ini adalah metode analisis deskriptif kualitatif yang nantinya hasil penelitian disajikan dalam bentuk tabel.

\section{HASIL DAN PEMBAHASAN}

\section{Identitas Responden}

\section{Umur Petani}

Responden petani menurut golongan umur dapat dilihat pada Tabel 1.

\section{Tabel 1. Jumlah Responden Menurut Golongan Umur}

\begin{tabular}{|l|l|c|c|}
\hline No. & $\begin{array}{c}\text { Kelompok } \\
\text { Umur (Tahun) }\end{array}$ & Jumlah & $\begin{array}{c}\text { Persentase } \\
(\%)\end{array}$ \\
\hline 1. & $25-40$ & 5 & 12,21 \\
2. & $41-50$ & 25 & 60,96 \\
3. & $51-60$ & 8 & 19,51 \\
4. & $>60$ & 3 & 7,32 \\
\hline & Jumlah & 41 & 100,00 \\
\hline
\end{tabular}

Sumber: Diolah dari Data Primer, 2016 
Data pada Tabel 1, menunjukkan bahwa sebagian besar petani responden mempunyai umur antara 41 sampai 50 tahun $(60,95 \%)$ kemudian umur 51-60 tahun $(19,51 \%)$ dan umur $25-40$ tahun $(12,21 \%)$. Jadi umur responden yang diwawancarai umumnya tergolong produktif.

\section{Tingkat Pendidikan}

Pendidikan responden dapat dilihat pada Tabel 2. Tabel 2. menunjukkan bahwa tingkat pendidikan responden yang terbanyak adalah SLTA $(36,58 \%)$ kemudian menyusul SLTP $(29,27 \%)$. Ini berarti tingkat pendidikan responden tergolong cukup baik, walaupun masih ada responden yang tidak tamat SD.

Tabel 2. Jumlah Responden Menurut Tingkat Pendidikan

\begin{tabular}{|c|l|c|c|}
\hline No. & Tingkat Pendidikan & Jumlah & $\begin{array}{c}\text { Persentase } \\
(\%)\end{array}$ \\
\hline 1. & Tidak Tamat SD & 11 & 26,83 \\
2. & SD & 3 & 7,32 \\
3. & SLTP & 12 & 29,27 \\
4. & SLTA & 15 & 36,58 \\
& & & \\
\hline & Jumlah & 41 & 100,00 \\
\hline
\end{tabular}

Sumber: Diolah dari Data Primer, 2016

\section{Luas Pemilikan Lahan}

Jumlah responden menurut luas pemilikan lahan dapat dilihat pada Tabel 3. Data pada Tabel 3, menunjukkan bahwa sebagian besar petani responden $(53,66 \%)$ mempunyai lahan dengan luas $1-2 \mathrm{Ha}$ kemudian yang memiliki luas lahan lebih kecil $1 \mathrm{Ha}(26,83 \%)$ dan luas lahan $>2 \mathrm{Ha}$ sebanyak $19,51 \%$.
Tabel 3. Jumlah Responden Menurut Luas Pemilikan Lahan

\begin{tabular}{|l|l|c|c|}
\hline No. & $\begin{array}{c}\text { Pemilikan } \\
\text { Lahan (Ha) }\end{array}$ & Jumlah & $\begin{array}{c}\text { Persentase } \\
(\%)\end{array}$ \\
\hline 1. & $<1$ & 11 & 26,83 \\
2. & $1-2$ & 22 & 53,66 \\
3. & $>2$ & 8 & 19,51 \\
\hline & Jumlah & 41 & 100,00 \\
\hline
\end{tabular}

Sumber: Diolah dari Data Primer, 2016

\section{Tingkat Pendapatan}

Jumlah responden menurut tingkat pendapatan dapat dilihat pada Tabel 4 .

\section{Tabel 4. Jumlah Responden Menurut Tingkat Pendapatan}

\begin{tabular}{|l|l|c|c|}
\hline No. & $\begin{array}{c}\text { Tingkat } \\
\text { Pendapatan } \\
\text { (Rp/Bulan) }\end{array}$ & Jumlah & $\begin{array}{c}\text { Persentase } \\
(\%)\end{array}$ \\
\hline 1. & $<1.000 .000$ & 8 & 19,51 \\
2. & $\begin{array}{l}1.000 .000- \\
2.000 .000\end{array}$ & 23 & 56,09 \\
3. & $>2.000 .000$ & 10 & 24,40 \\
\hline & Jumlah & 41 & 100.00 \\
\hline
\end{tabular}

Sumber: Diolah dari Data Primer, 2016

Data pada Tabel 4 menunjukkan bahwa sebagian besar petani responden $(56,09 \%)$ mempunyai pendapatan antara $\mathrm{Rp} 1.000 .000$ sampai dengan $\mathrm{Rp} 2.000 .000$ kemudian pendapatan lebih besar Rp 2.000.000 (24,40\%) dan lebih kecil dari Rp 1.000.000 (19,51\%).

\section{Tingkat Adopsi Inovasi Padi Sawah Organik}

Tingkat adopsi petani responden terhadap padi sawah organik dapat dilihat pada Tabel 5. Data pada Tabel 5, menunjukkan 
bahwa sebagian besar petani responden $(56,19 \%)$ telah mengadopsi atau menerapkan inovasi padi sawah organik di lahan sawahnya secara rutin.

Tabel 5 Tingkat Adopsi Inovasi Padi Sawah Organik oleh Petani

\begin{tabular}{|l|l|c|c|}
\hline No. & \multicolumn{1}{|c|}{$\begin{array}{c}\text { Tingkat } \\
\text { Adopsi }\end{array}$} & Jumlah & $\begin{array}{c}\text { Persentase } \\
(\%)\end{array}$ \\
\hline 1. & Kesadaran & 2 & 4,78 \\
2. & Keinginan & 5 & 12,20 \\
4. & Menilai & 4 & 9,76 \\
5. & $\begin{array}{l}\text { Mencoba } \\
\text { (Adopsi) }\end{array}$ & 7 & 17,07 \\
\hline & Jumlah & 41 & 100,00 \\
\hline
\end{tabular}

Sumber: Diolah dari Data Primer, 2016

Kemudian petani yang masih dalam tahap mencoba inovasi padi sawah organik sebanyak $17,07 \%$, petani yang masih dalam tahap menilai inovasi padi sawah organik sebesar 9,76\%, selanjutnya petani yang termasuk dalam tahap keinginan sebesar $12,20 \%$ dan akhirnya yang masih tahap awal atau tahap kesadaran sebesar $4,78 \%$.

\section{Penggolongan Petani}

Penggolongan petani berdasarkan kecepatan mengadopsi inovasi padi sawah organik dapat dilihat pada Tabel 6. Data pada Tabel 6, menunjukkan bahwa petani yang tergolong innovator terdapat 8 responden $(19,51 \%)$. Golongan petani ini telah menerapkan inovasi padi sawah organik sejak Tahun 2012. Kemudian golongan petani pengetrap dini merupakan golongan yang terbanyak (36,59\%). Golongan ini sudah menerapkan inovasi padi sawah organik sejak Tahun 2014 dan aktif dalam kegiatan kelompok tani. Selanjutnya golongan petani pengetrap awal sebesar $26,83 \%$ yang sudah menerapkan inovasi tanaman padi sawah organik sejak Tahun 2016.
Tabel 6. Penggolongan Petani berdasarkan Kecepatan Adopsi

\begin{tabular}{|l|l|c|c|}
\hline No. & Tipe Petani & Jumlah & Persentase (\%) \\
\hline 1. & Innovator & 8 & 19,51 \\
2. & Pengetrap Dini & 15 & 36,59 \\
3. & Pengetrap Awal & 11 & 26,83 \\
4. & Pengetrap Akhir & 6 & 14,63 \\
5. & Penolak & 1 & 2,44 \\
\hline & Jumlah & 41 & 100,00 \\
\hline
\end{tabular}

Sumber: Diolah dari Data Primer, 2016

Demikian juga golongan petani pengetrap akhir sebesar 14,63\% yang baru dalam penilaian terhadap tanaman padi sawah organik, sedangkan golongan penolak sebesar $2,44 \%$ baru mengenal tanaman padi sawah organik dan belum bersedia menanam padi tersebut.

\section{Hubungan antara Tingkat Adopsi dengan Umur}

Hubungan umur responden dengan tingkat adopsi inovasi tanaman padi sawah organik dapat dilihat pada Tabel 7. Data pada Tabel 7, menunjukkan kecenderungan petani berumur muda yakni 40 sampai 50 tahun yang terbanyak menerapkan inovasi tanaman padi sawah organik.

\section{Hubungan antara Tingkat Adopsi dengan Pendidikan}

Hubungan tingkat pendidikan responden dengan tingkat adopsi padi sawah organik dapat dilihat pada Tabel 8 . Tabel 8 menunjukkan bahwa petani yang memiliki pendidikan SLTA dan SLTP lebih banyak yang telah menerapkan atau mengadopsi inovasi tanaman padi sawah organik.

\section{Hubungan antara Tingkat Adopsi dengan Luas Pemilikan Lahan}

Hubungan luas pemilikan lahan responden dengan tingkat adopsi padi sawah 
organik dapat dilihat pada Tabel 9. Tabel 9 menunjukkan bahwa kecenderungan petani yang memiliki lahan 1 sampai 2 Ha yang paling banyak menerapkan inovasi tanaman padi sawah organik. Ini berarti pemilikan lahan yang luas cenderung tingkat adopsinya lebih tinggi.

\section{Hubungan antara Tingkat Adopsi dengan Tingkat Pendapatan}

Hubungan Tingkat pendapatan responden dengan tingkat adopsi padi sawah organik dapat dilihat pada Tabel 10. Tabel 10 menunjukkan bahwa pendapatan di atas Rp 1.000 .000 per bulan yang paling banyak menerapkan inovasi tanaman padi sawah organik. Ini berarti bahwa makin tinggi pendapatan petani maki tinggi pula tingkat adopsinya.

Tabel 7 . Umur Responden dengan Tingkat Adopsi Inovasi Padi Sawah Organik

\begin{tabular}{|l|cccc|c|}
\hline Tingkat Adopsi & \multicolumn{5}{|c|}{ Umur (Tahun) } \\
\cline { 2 - 5 } & $25-40$ & $41-50$ & $51-60$ & $>60$ & Jumlah \\
\hline Kesadaran & - & - & - & 2 & 2 \\
Keinginan & 1 & 3 & - & 1 & 5 \\
Menilai & 2 & 1 & 1 & - & 4 \\
Mencoba & 2 & 2 & 3 & - & 7 \\
\hline Jumlah & - & 19 & 4 & - & 23 \\
\hline
\end{tabular}

Sumber: Diolah dari Data Primer, 2016

Tabel 8. Pendidikan Responden dengan Tingkat Adopsi Padi Sawah Organik

\begin{tabular}{|l|cccc|c|}
\hline Tingkat Adopsi & \multicolumn{4}{|c|}{ Tingkat Pendidikan } & Jumlah \\
\cline { 2 - 5 } & TTSD & SD & SLTP & SLTA & \\
\hline Kesadaran & 2 & - & - & - & 2 \\
Keinginan & 3 & 2 & - & - & 5 \\
Menilai & 4 & - & - & - & 4 \\
Mencoba & 1 & 1 & 3 & 2 & 7 \\
Menerapkan & 1 & - & 9 & 13 & 23 \\
\hline Jumlah & 11 & 3 & 12 & 15 & 41 \\
\hline
\end{tabular}

Sumber: Diolah dari Data Primer, 2016 
Tabel 9. Luas Pemilikan Lahan Responden dengan Tingkat Adopsi Padi Sawah Organik

\begin{tabular}{|l|ccc|c|}
\hline Tingkat Adopsi & \multicolumn{3}{|c|}{ Luas Pemilikan Lahan (Ha) } & Jumlah \\
\cline { 2 - 4 } & $<1$ & $1-2$ & -2 \\
\hline Kesadaran & 2 & - & - & 2 \\
Keinginan & 3 & 2 & - & 5 \\
Menilai & 4 & - & 5 & 4 \\
Mencoba & 1 & 1 & 3 & 7 \\
Menerapkan (Adopsi) & 1 & 19 & 8 & 23 \\
\hline Jumlah & 11 & 22 & & 41 \\
\hline
\end{tabular}

Sumber: Dolah dari Data Primer, 2016

Tabel 10. Pendapatan Responden dengan Tingkat Adopsi Padi Sawah Organik

\begin{tabular}{|c|c|c|c|c|}
\hline \multirow[t]{2}{*}{ Tingkat Adopsi } & \multicolumn{3}{|c|}{ Tingkat Pendapatan (Rp/Bulan) } & \multirow[t]{2}{*}{ Jumlah } \\
\hline & $<1$ juta & 1 juta- 2 juta & $>2$ juta & \\
\hline Kesadaran & 2 & - & - & 2 \\
\hline Keinginan & 2 & 3 & - & 5 \\
\hline Menilai & 3 & 1 & - & 4 \\
\hline Mencoba & 1 & 2 & 4 & 7 \\
\hline $\begin{array}{l}\text { Menerapkan } \\
\text { (Adopsi) }\end{array}$ & - & 17 & 6 & 23 \\
\hline Jumlah & 8 & 23 & 10 & 41 \\
\hline
\end{tabular}

Sumber: Diolah dari Data Primer, 2016 


\section{KESIMPULAN DAN SARAN}

\section{Kesimpulan}

Berdasarkan uraian sebelumnya dapat disimpulkan bahwa:

a. Tingkat adopsi petani terhadap inovasi padi sawah organik di Desa Molompar

Kecamatan Tombatu Timur cukup tinggi dimana sebagian besar petani telah menerapkan atau mengadopsi padi sawah organik.

b. Berdasarkan kecepatan adopsi petani terhadap inovasi padi sawah organik, golongan petani pengetrap dini dan pengetrap awal paling banyak di Desa Molompar Kecamatan Tombatu Timur.

c. Terdapat hubungan antara tingkat umur, pendidikan, luas pemilikan lahan dan pendapatan dengan adopsi petani terhadap inovasi padi sawah organik . Umur muda, pendidikan lebih tinggi, pemilikan lahan yang luas, dan pendapatan yang tinggi cenderung tingkat adopsi petani terhadap inovasi padi sawah organik lebih tinggi.

\section{Saran}

a. Penyuluhan perlu ditingkatkan agar semua petani mengadopsi inovasi padi sawah organik.

b. Golongan petani yang perlu mendapat perhatian penyuluh pertanian adalah golongan pengetrap dini dan golongan pengetrap awal.

\section{DAFTAR PUSTAKA}

Andoko A, 2002. Budidaya Padi Secara Organik. Cetakan I, Penebar Swadaya, Jakarta. Balitpang , 1989, Padi

Lionberger , H.F. 1960. Adoption of New Ideas and Practices. The IOWA State University.

Mardikanto, T. 1988, Komunikasi Pembangunan. UPT Penerbitan dan Pencetakan UNS (UNS Press). Surakarta

Rogers, E, M, 1983. Diffusion of Innovations. London: The Free Press.

Sumarto, Hetifa Sj. 2003. Inovasi, Partisipasi, dan Good Governance, Bandung: Yayasan. Obor Indonesia.

Suparyono \& Agus Setyono, Dr. 1994. Padi. Penebar Swadaya. Jakarta. 